\title{
Morphing Switched-Capacitor Converters with Variable Conversion Ratio
}

\author{
Song Xiong, Ying Huang, Siew-Chong Tan Senior Member, IEEE, and Shu Yuen (Ron) Hui Fellow, IEEE
}

\begin{abstract}
High-voltage-gain and wide-input-range DC-DC converters are widely used in various electronics and industrial products such as portable devices, telecommunication, automotive, and aerospace systems. The two-stage converter is a widely adopted architecture for such applications, and it is proven to have a higher efficiency as compared with the single-stage converter. This paper presents a modular-cell-based morphing switched-capacitor (SC) converter for application as a front-end converter of the two-stage converter. The conversion ratio of this converter is flexible and can be freely extended by increasing more SC modules. The varying conversion ratio is achieved through the morphing of the converter's structure corresponding to the amplitude of the input voltage. This converter is light and compact, and is highly efficient over a very wide range of input voltage and load conditions. Experimental work on a $25 \mathrm{~W}, 6 \mathrm{~V}-30 \mathrm{~V}$ input, $3.5 \mathrm{~V}-8.5 \mathrm{~V}$ output prototype, is performed. For a single SC module, the efficiency over the entire input voltage range is higher than $98 \%$. Applied into the two-stage converter, the overall efficiency achievable over the entire operating range is $80 \%$.
\end{abstract}

\section{INTRODUCTION}

High-voltage-gain DC-DC converters are widely applied in various electronics and industrial products such as portable devices, telecommunication systems, automotive systems, and aerospace systems, where the common power bus voltage (e.g. $12 \mathrm{~V}, 24 \mathrm{~V}, 48 \mathrm{~V}$ ) is much higher than the voltage of the loads required (e.g. 1V-1.8 $\mathrm{V}$ for point-of-loads [1], [2], 0.4 V for processor's supply voltage by 2026 [3]). To increase the power reliability of the system, a battery backup sub-system is typically required in the system to ensure continuous power provision. On the other hand, the output voltage of a battery can vary widely according to its state-of-charge, e.g. $18 \mathrm{~V}-58 \mathrm{~V}$ for $42 \mathrm{~V}$ automotive system [4], [5], $36 \mathrm{~V}-72 \mathrm{~V}$ in telecommunication applications [6]. Therefore, systems with battery as their main/backup power source will require their converters to work with a wide input voltage range. Additionally, the converters should be of high power density due to the limited size and weight allowance given in portable devices, automotive systems and aerospace systems. A higher weight of the power converter will in turn lead to more transport energy being required in the automotive and aerospace systems. Therefore, the design of a high-voltage-gain, wide-input-range, high-power-density, high-efficiency converter is important.

A conventional solution applied to high-voltage-gain conversion is through the use of single-stage non-isolated converters, e.g. the buck converter. This, however, will require the buck converter to work at an extremely low duty ratio, i.e. $D=\frac{V_{o}}{V_{i n}}$, which leads to many issues. First, the on-time of the high-side switch is extremely low at high switching frequency (necessary for the reduction of the converter's size and weight). This extremely low on-time necessitates the use of a high-performance switch. Second, operating the converter at a very low duty cycle gives a low efficiency [7], [8]. Third, the extremely low duty ratio also limits the dynamic respond as the room of reducing the duty ratio is limited [5]. Fourth, there is a limit to the operating input voltage range of the converter [9]. This is similar for other single-stage converters, such as the buck-boost, Ćuk, Sepic, and Zeta converters. 
Recently, the series-input-parallel-output (SIPO) connected converter, which is composed of many DC-DC converter modules, has been sought after as a possible candidate for high-voltage-gain conversion [1], [3], [6], [10]-[12]. The input voltage of each converter module in the SIPO converter is only a fraction of the actual input voltage since the inputs of the modules are serially connected. The SIPO converter has two advantages. First, the conversion ratio of each converter module in the SIPO converter is lower than that conventionally required as the modules are sharing the input voltage, while the output voltage is unchanged. Second, the power level of each module in the SIPO converter is a fraction of the total output power since they are sharing the task of the power processing. Both these advantages are critical for the efficiency improvement of each converter module. Therefore, the overall efficiency of the SIPO converters can be high [1], [3], [6], [10]-[12]. On the down side, however, the dynamic response of these converters will be poor, and they suffer from being bulky and heavy due to the need for multiple inductors in the converter.

Alternatively, transformer-based converters, such as LLC resonant converter, and dual-active-bridge (DAB) converter, etc. [13]-[15], have also been used for the high-voltage-gain conversion application. For these converters, the transformer is the core component used for achieving the high-voltage conversion. To increase the converter's compactness, high-frequency operation is required to reduce the reactive components' size and weight since they are the bulkiest components in these converters. To reduce the switching losses caused by the high switching frequency, zero-voltage-switching (ZVS) and zero-current-switching (ZCS) techniques are often applied [13]-[16]. However, converters that are applied with ZVS and ZCS techniques are generally unsuitable for applications requiring a wide input voltage range as they will lose the soft switching function if the input voltage deviates away from the nominal input voltage. Moreover, the leakage inductance of the transformer can lead to significant power losses [17]. A simple approach of reusing the energy from the leakage inductance is by retrieving it to achieve ZVS for the switches [13]-[16]. Another approach is to insert an active clamp circuit to recycle the leakage energy [18]. Furthermore, for applications with a wide input voltage range, the control loop design of the converter is difficult. The feed-forward control is necessary for eliminating the effect of a large input variation. This increases the complexity of the control circuit [5]. Besides, for low power applications where galvanic isolation is not mandatary, the use of transformer will be excessive and costly as compared to non-isolated solutions.

The two-stage converter, which is found capable of having an overall higher efficiency than that of a single-stage DC-DC converter in high-voltage-gain applications [7], [8], [19]-[25], is the trend moving forward and has been applied in industry. In the two-stage architecture, the first-stage converter is typically used for stepping down of the input voltage to an intermediate bus voltage efficiently, and the second-stage converter performs both the stepping down of the input voltage and the regulation of the output voltage with high efficiency and tight regulation. Note that the first-stage front-end converter can output a regulated or unregulated intermediate bus voltage.

In this paper, the architecture of the two-stage converter is adopted for the high-voltage-gain and wide-input-voltage range application, where the output of the front-end converter is unregulated. Here, a variable-conversion-ratio morphing switchedcapacitor (SC) converter is proposed for application as the front-end converter. This morphing SC converter is composed of many highly-efficient modules of SC cells, of which the variable conversion ratio is achieved through the morphing control of the SC converter. The principle is to morph the operating number of modular SC cells according to the amplitude of the input voltage of the front-end converter to achieve the highest possible conversion efficiency. This variable-conversion-ratio morphing SC converter has many advantages.

(a) The conversion ratio of this converter is adapted to the input voltage to give a specified range of output voltage. For conventional SC converter used for performing only voltage transformation, the conversion ratio is typically fixed. When the 
input voltage varies, the output voltage will also vary [26]-[46].

(b) Each SC module is optimally design to achieve a very high efficiency. The efficiency of a single SC module is higher than $98 \%$.

(c) The converter is easily extendable with the additional cascade of more SC modules. The maximum conversion ratio can be freely increase by the incorporation of more SC modules.

(d) It is highly compact with low weight and small size. SC converters are composed of switches and capacitors, and does not contain any magnetic element. It can be easily fabricated as an integrated-circuit (IC) chips [47]-[49].

(e) The modular design leads to many advantages, such as availability, maintainability, flexible system structure, and layout [2].

\section{Proposed Morphing SC CONVERTER}

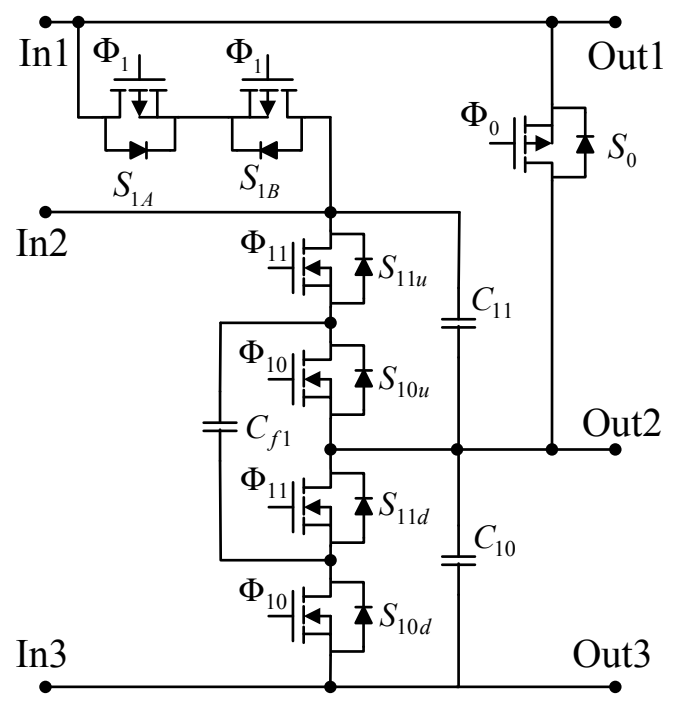

(a)

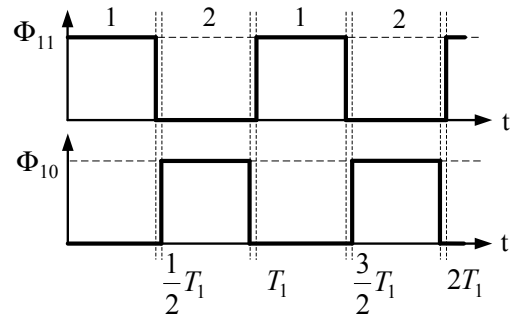

(b)

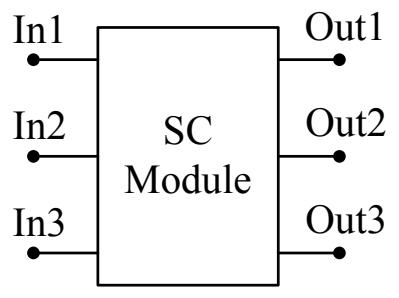

(c)

Fig. 1. (a) Topology, (b) timing diagram and (c) block diagram of the SC cell.

Fig. 1(a) shows the topology of a module of the SC cell of the proposed morphing SC converter. It contains three input and three output ports. The power source is connected to ports In1 (+ve) and In3 (-ve), and the load is connected to ports Out2 (+ve) and Out3 (-ve). Ports In2 and Out1 are extension ports for the connection of an additional SC module to the morphing SC converter. The SC cell has two operation modes, which are shown in Fig. 2. In Mode 1, the voltage conversion ratio is 1, which is shown in Fig. 2(a). In this mode, only switch $S_{0}$ is turned on, and all other switches are off. The output is directly connected to the input via the switch $S_{0}$. In Mode 2, the voltage conversion ratio is 0.5, which is shown in Fig. 2(b). In this mode, switch $S_{0}$ is off, switches $S_{1 A}$ and $S_{1 B}$ are turning ON, and switches $S_{11 u}, S_{11 d}, S_{10 u}$ and $S_{10 d}$ are operated with the timing diagram shown in Fig. 1(b). Therefore, there are two operating states in Mode 2, as shown in Fig. 3. 
In State 1 of Mode 2 (see Fig. 3(a)), the flying capacitor $C_{f 1}$ is connected in parallel with the bypass capacitor $C_{11}$. At the end of this state, $V_{f 1}=V_{11}$. In State 2 of Mode 2 (see Fig. 3(b)), the flying capacitor $C_{f 1}$ is connected in parallel with the bypass capacitor $C_{10}$. At the end of this state, $V_{10}=V_{f 1}$. Here, $V_{10}=V_{11}=V_{f 1}=\frac{V_{i n}}{2}$. The output voltage equals to $V_{10}$. Hence, the conversion ratio is $\frac{V_{o}}{V_{i n}}=0.5$. A simplified block diagram of the SC cell is shown in Fig. 1(c).

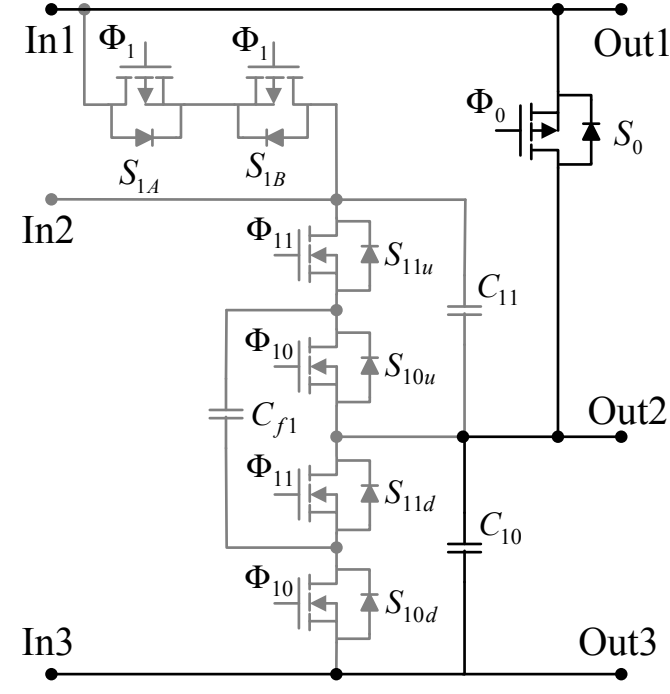

(a)

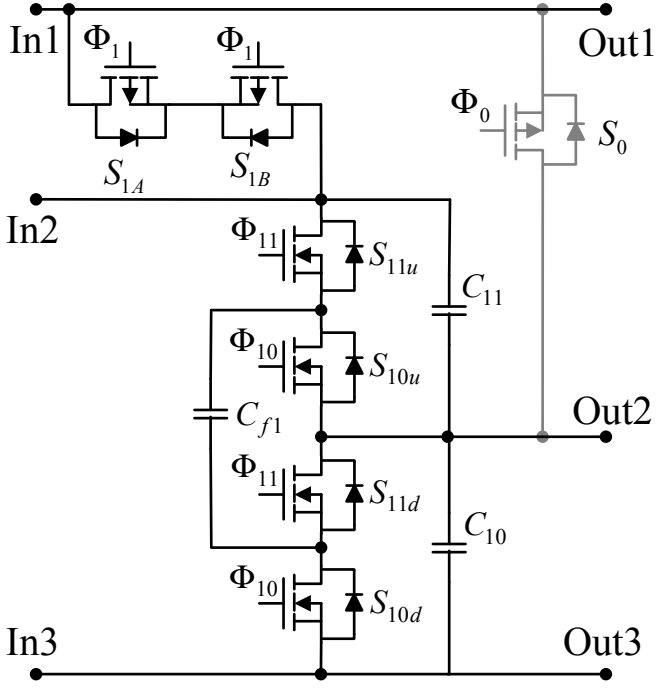

(b)

Fig. 2. Operation modes of basic SC cell at conversion ratio (a) 1 and (b) 0.5 .

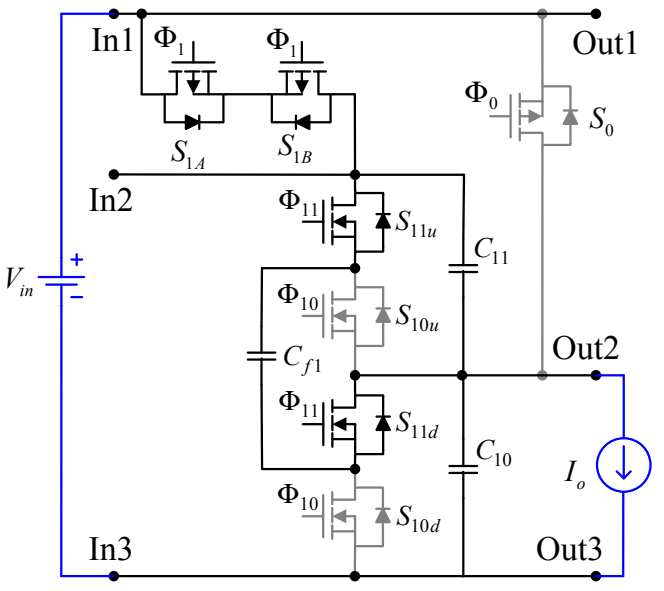

(a)

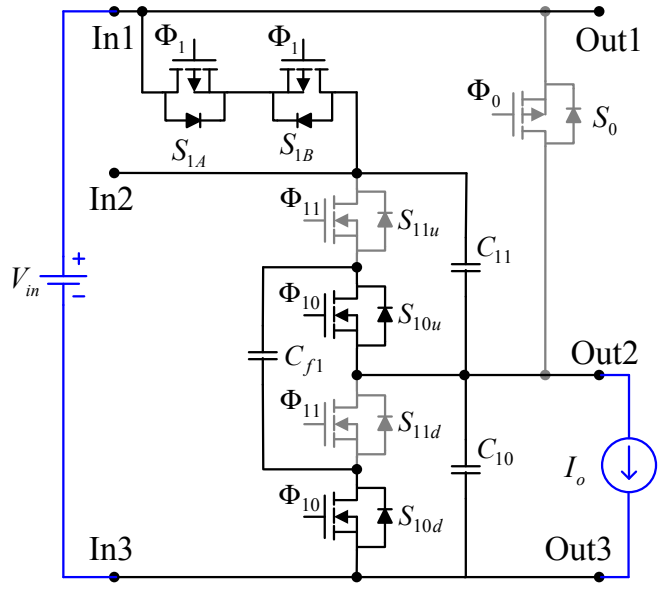

(b)

Fig. 3. The two operating states of Mode 2. (a) State 1 and (b) State 2 of the basic SC cell at conversion ratio of 0.5 .

The proposed morphing SC converter is composed of $N$ number of SC cells connected in cascade as shown in Fig. 4. The three input ports (In1, In2, and In3) of $k$-th cell is connected to the three output ports (Out1, Out2, and Out3) of the $(k-1)$-th cell, where $k=2 \cdots N$. The power source is connected to the input ports In1 and In3 of the first cell, and the load is connected to the output ports Out 2 and Out 3 of the $N$-th cell. This $N$-module morphing SC converter has $N+1$ conversion ratios, which are $0.5^{j}$, where $j=0 \cdots N$. 


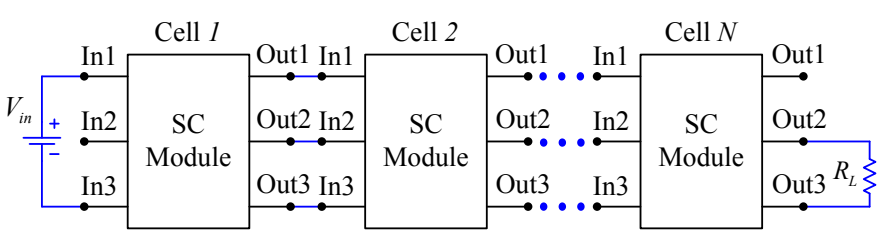

Fig. 4. Proposed morphing SC converter with $N$ SC cells.

\section{OPERATION OF THE TWO-MODULE MORPHING SC CONVERTER}

For convenience sake, a two-module morphing SC converter as shown in Fig. 5(a) is hereon used for the detailed discussion of the operation and properties of the morphing SC converter. Fig. 5(b) shows the pair of complementary PWM signals for cell 1 and cell 2. Figs. 6(a)-6(c) show the three operation modes of the two-module morphing SC converter, which gives the conversion ratios of $1,0.5$ and 0.25 , respectively.

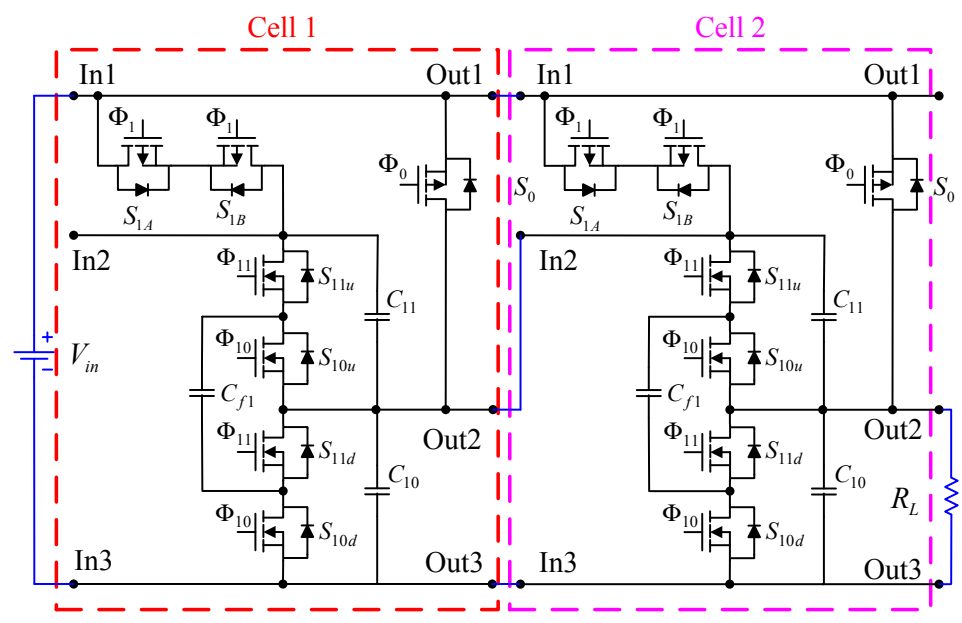

(a)

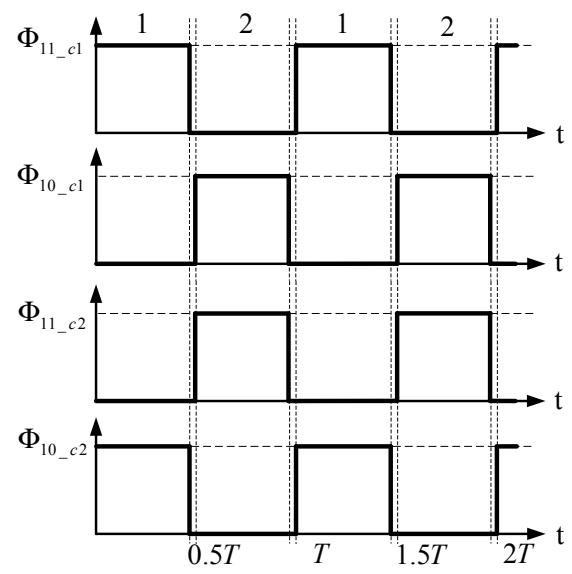

(b)

Fig. 5. (a) Topology of two-module morphing SC converter and its (b) control PWM signals.

\section{A. Three Operation Modes of the Two-Module Morphing SC Converter}

(1) The first mode (Mode 1) is shown in Fig. 6(a), of which the conversion ratio is 1. Here, only $S_{0}$ of cell 2 is turned on, while all other switches are off. As only $S_{0}$ of cell 2 is working, the only conduction loss is on $S_{0}$. Therefore, the converter is of high efficiency.

(2) In Mode 2 as shown in Fig. 6(b), the conversion ratio is 0.5. Here, cell 1 is shut down. Switch $S_{0}$ of cell 2 is off, while switches $S_{1 A}$ and $S_{1 B}$ of cell 2 are turned on. The switches $S_{11 u}, S_{11 d}, S_{10 u}$ and $S_{10 d}$ of cell 2 are driven by the control signal of $\Phi_{11 \_c 2}$, and $\Phi_{10 \_c 2}$ given in Fig. 5(b).

(3) In Mode 3 as shown in Fig. 6(c), the conversion ratio is 0.25. Here, both cell 1 and cell 2 are in operation. Switch $S_{0}$ of cell 1, and switches $S_{1 A}, S_{1 B}$ and $S_{0}$ of cell 2 are off. The switches $S_{1 A}$ and $S_{1 B}$ of cell 1 are turned on. Switches $S_{11 u}$, $S_{11 d}, S_{10 u}$ and $S_{10 d}$ of cell 1 are driven by the timing diagram of $\Phi_{11_{-} c 1}$, and $\Phi_{10_{-} c 1}$ given in Fig. 5(b). The switches $S_{11 u}$, $S_{11 d}, S_{10 u}$ and $S_{10 d}$ of cell 2 are driven by control signals $\Phi_{11_{c} c 2}$, and $\Phi_{10 \_c 2}$ which are complementary to that of cell 1 , and are shown in Fig. 5(b).

The control signal required for driving the two-module morphing SC converter is summarized as shown in Table I. 


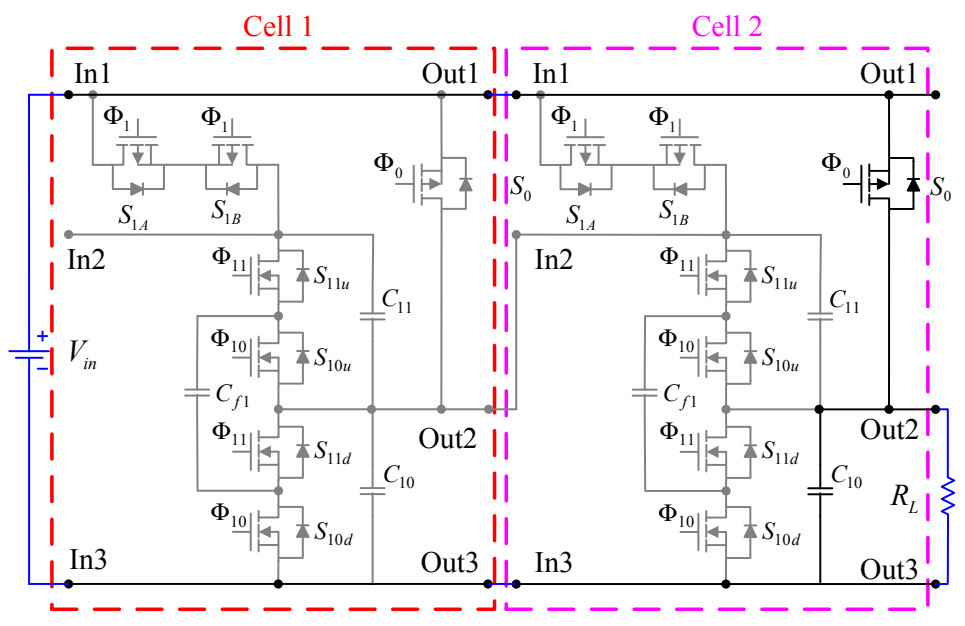

(a) Mode 1

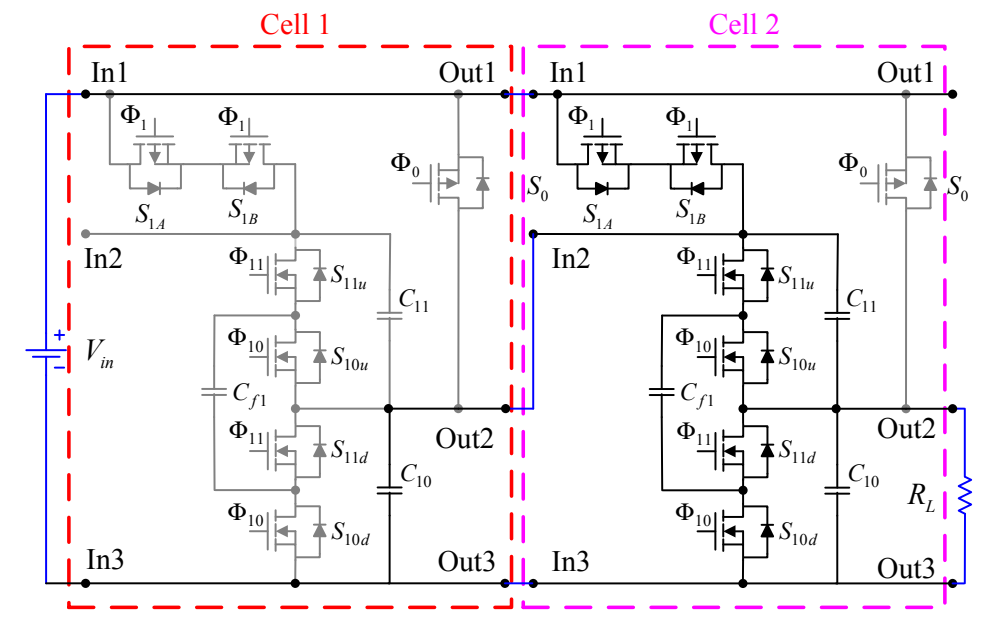

(b) Mode 2

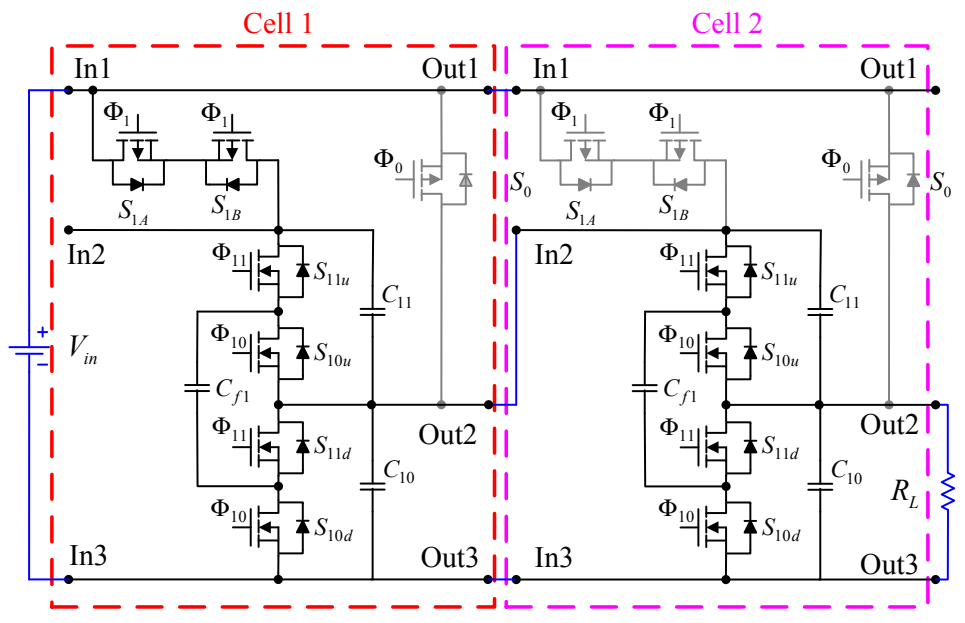

(c) Mode 3

Fig. 6. Three operation modes of two-module morphing SC converter. (a) Mode 1, (b) Mode 2 and (c) Mode 3. 
TABLE I

CONTROL SIGNAL OF TWO-MODULE MORPHING SC CONVERTER.

\begin{tabular}{|c|c|c|c|c|c|c|c|c|}
\hline \multirow{2}{*}{ Mode } & \multicolumn{4}{|c|}{ Cell 1} & \multicolumn{4}{|c|}{ Cell 2} \\
\hline & $S_{0}$ & $S_{1 A}, S_{1 B}$ & $S_{11 u}, S_{11 d}$ & $S_{10 u}, S_{10 d}$ & $S_{0}$ & $S_{1 A}, S_{1 B}$ & $S_{11 u}, S_{11 d}$ & $S_{10 u}, S_{10 d}$ \\
\hline Mode 1 & OFF & OFF & OFF & OFF & $\mathrm{ON}$ & OFF & OFF & OFF \\
\hline Mode 2 & OFF & OFF & OFF & OFF & OFF & $\mathrm{ON}$ & $\Phi_{11 \_c 2}$ & $\Phi_{10 \_c 2}$ \\
\hline Mode 3 & OFF & ON & $\Phi_{11 \_c 1}$ & $\Phi_{10 \_c 1}$ & OFF & OFF & $\Phi_{11 \_c 2}$ & $\Phi_{10 \_c 2}$ \\
\hline
\end{tabular}

\section{B. Control Methodology}

The mode selection control diagram of the two-module morphing SC converter is shown in Fig. 7(a), and Fig. 7(b) shows the converter's operating mode at different input voltage. The two-module morphing SC converter has four mode transition voltages. When the input voltage of the two-module morphing SC converter is increased to $V_{a c t, 12}$, the converter is changed from Mode 1 ( $\left.M_{1 \text { increase }}\right)$ to Mode 2 ( $\left.M_{2 \text { increase }}\right)$, and when the converter's input voltage is increased to $V_{a c t, 23}$, it is changed from Mode 2 ( $\left.M_{2 \text { increase }}\right)$ to Mode 3 ( $\left.M_{3 \text { increase }}\right)$. When the converter's input voltage is decreased to $V_{a c t, 32}$, the two-module morphing SC converter is changed from Mode 3 ( $\left.M_{3 \text { decrease }}\right)$ to Mode 2 ( $\left.M_{2 \text { decrease }}\right)$, and when the converter's input voltage is decreased to $V_{a c t, 21}$, it is changed from Mode $2\left(M_{2 \text { decrease }}\right)$ to Mode 1 ( $\left.M_{1 \text { decrease }}\right)$. By adopting this control approach, the output voltage will be in a small range as shown in Fig. 7(c).

The overview of the control method is shown in Fig. 8. The input voltage range detector is to detect the input voltage range, which will be used to determine the operation mode of the two-module morphing SC converter and it will also determine the PWM signals of the two module cells.

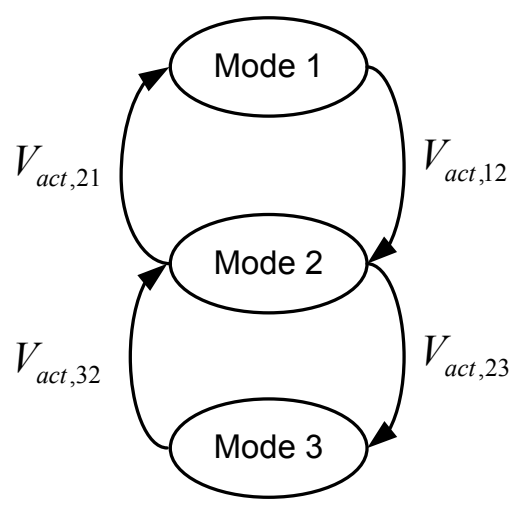

(a)

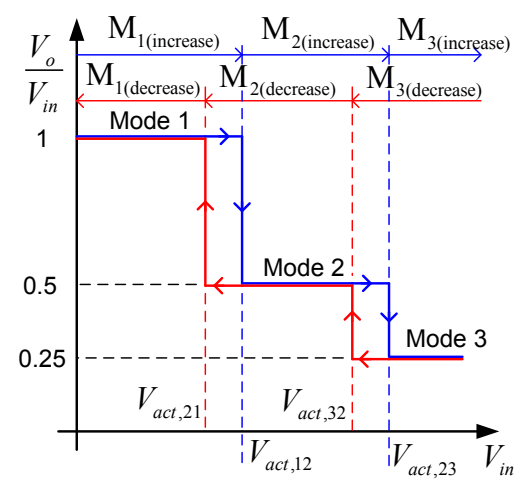

(b)

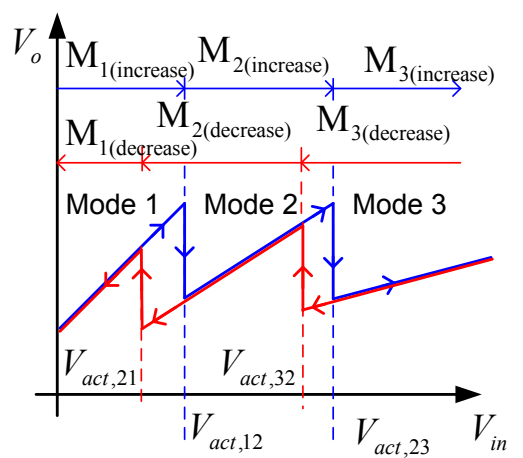

(c)

Fig. 7. Mode morphing diagram of the two-module morphing SC converter. (a) Mode selection diagram, (b) operation mode at different input voltage, and (c) the output voltage versus the input voltage plot.

\section{EFFICIENCY ESTIMATION OF THE MORPHING SC CONVERTER}

\section{A. SC Cell Efficiency}

(a) Efficiency estimation of Mode 1.

For Mode 1, the efficiency of the converter is

$$
\eta=\frac{V_{\text {in }}-R_{d s o n} \cdot I_{o}}{V_{\text {in }}} \times 100 \%,
$$

where $R_{d s o n}$ is the on resistance of the MOSFET of $S_{0}$ and $I_{o}$ is the output current of the converter. 


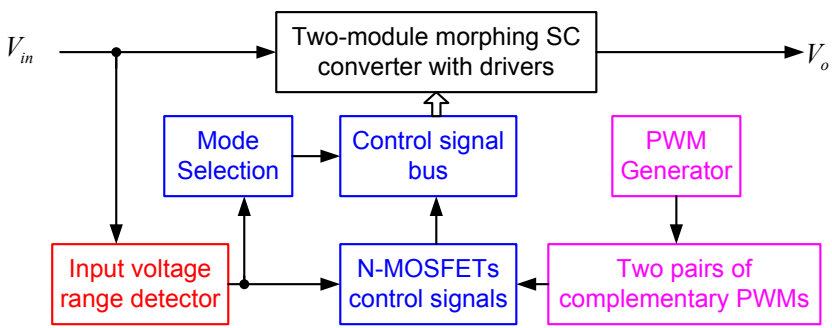

Fig. 8. Control block diagram of the two-module morphing SC converter.

(b) Efficiency estimation of Mode 2.

By adopting the discrete-time ananlysis approach introduced in [25], the voltage of the capacitor is assumed to be linear in a short interval $\Delta t$, and there are $N$ short intervals within a period $T$, i.e. $\Delta t=\frac{T}{N}$. Therefore, the capacitor voltage in a period can be expressed as a sequence of $V(0), V(1), \cdots, V(i), \cdots, V(N)$, with the capacitor voltage in the $i$-th interval being $v\left(\frac{i T}{N}+t\right)=V(i-1)+\frac{T(V(i)-V(i-1))}{N} t$. Therefore, the current can be expressed as a sequence of $I(1), I(2), \cdots, I(i), \cdots, I(N)$, and in each interval the capacitor current is a constant following the equation

$$
I(i)=C \frac{\Delta V}{\Delta t}=C \frac{V(i)-V(i-1)}{T / N} .
$$

Therefore,

$$
V(i)=V(i-1)+R_{e q} I(i)
$$

where

$$
R_{e q}=\frac{T}{N C} .
$$

Therefore, by adopting this discrete-time analysis, the capacitor at the $i$-th interval (refer to Fig. 9(a)) can be equivalent to the model shown in Fig. 9(b), which is a voltage source series connected with a resistor, where the value of the voltage source is the capacitor's voltage of previous interval $V(i-1)$ and the resistor value is calculated by (4).

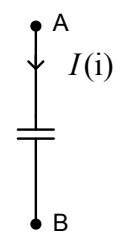

(a)

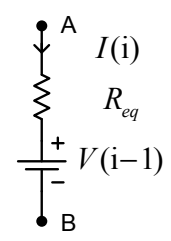

(b)

Fig. 9. (a) A capacitor and (b) its equivalent model.

By substituting the capacitor model shown in Fig. 9(b) to all states of the basic SC cell shown in Fig. 3 give the equivalent circuits as shown in Fig. 10. For the capacitors in the SC cell, the relationship of their voltages and currents can be obtained as

$$
\mathbf{V}(i)=\mathbf{V}(i-1)+\mathbf{R}_{e q} \mathbf{I}(i),
$$

where

$$
\begin{aligned}
\mathbf{V}(i) & =\left[V_{10}(i), V_{11}(i), V_{f 1}(i)\right]^{T} \text { and } \\
\mathbf{I}(i) & =\left[I_{10}(i), I_{11}(i), I_{f 1}(t)\right]^{T}
\end{aligned}
$$




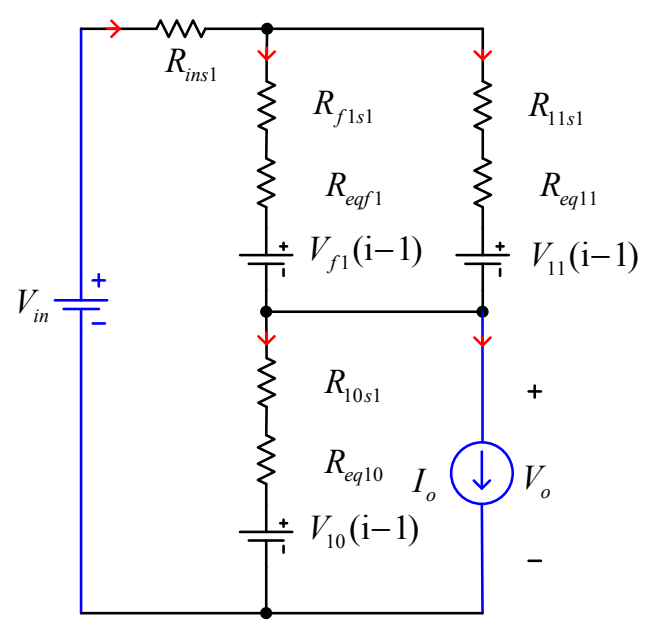

(a)

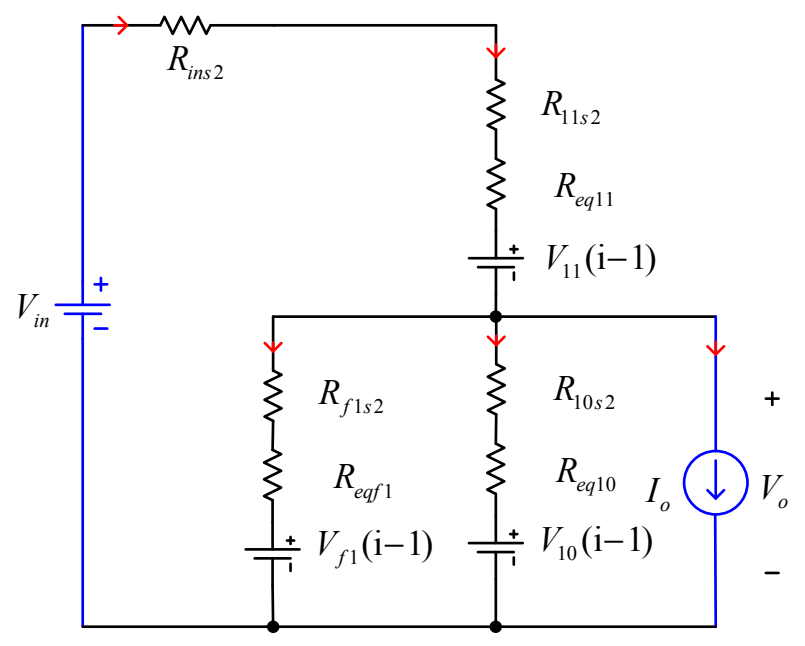

(b)

Fig. 10. Equivalent model of basic SC module of (a) state 1 shown in Fig. 3(a) and (b) state 2 shown in Fig. 3(b).

are the state-column vectors at time $i$, and

$$
\mathbf{R}_{e q}=\left[\begin{array}{ccc}
R_{e q 10} & 0 & 0 \\
0 & R_{e q 11} & 0 \\
0 & 0 & R_{e q f 1}
\end{array}\right]
$$

is the equivalent-resistance diagonal matrix with element $R_{e q x x}=\frac{T}{N C_{x x}}$, where the subscript $x x=10,11$ and $f 1$. According to the equivalent model shown in Fig. 10, for each state $k=1,2$, a general state equation can be calculated as

$$
\begin{aligned}
\mathbf{V}(i) & =\mathbf{A}_{k} \mathbf{V}(i-1)+\mathbf{B}_{k} \mathbf{U}_{k}, \text { where } \\
\mathbf{A}_{k}= & {\left[\begin{array}{lll}
a_{k, 11} & a_{k, 12} & a_{k, 13} \\
a_{k, 21} & a_{k, 22} & a_{k, 23} \\
a_{k, 31} & a_{k, 32} & a_{k, 33}
\end{array}\right], } \\
\mathbf{B}_{k}= & {\left[\begin{array}{ll}
b_{k, 11} & b_{k, 12} \\
b_{k, 21} & b_{k, 22} \\
b_{k, 31} & b_{k, 32}
\end{array}\right], \text { and } } \\
\mathbf{U}_{k}= & {\left[\begin{array}{l}
V_{\text {in }}(i) \\
I_{o}(i)
\end{array}\right] . }
\end{aligned}
$$

The single SC cell is operated at duty ratio of 0.5, which means the lasting time of the two states shown in Fig. 10 are the same. Assume that the lasting time of each state is $M$ intervals, hence, $N=2 M$. According to (9), the capacitors' voltage of the last interval in $k$-th state is

$$
\mathbf{V}(k M)=\mathbf{A}_{k}^{M} \mathbf{V}((k-1) M)+\left(\mathbf{A}_{k}-\mathbf{I}\right)^{-1}\left(\mathbf{A}_{k}^{M}-\mathbf{I}\right) \mathbf{B}_{k} \mathbf{U}_{k} .
$$

At steady state, the initial voltage of the first state equals the final voltage of the last state, i.e.

$$
\mathbf{V}(2 M)=\mathbf{V}(0)
$$


Hence, using (14), the steady-state solution can be obtained as

$$
\mathbf{V}(0)=\left(\mathbf{I}-\mathbf{A}_{1}^{M} \mathbf{A}_{2}^{M}\right)^{-1}\left[\mathbf{A}_{2}^{M}\left(\mathbf{A}_{1}-\mathbf{I}\right)^{-1}\left(\mathbf{A}_{1}^{M}-\mathbf{I}\right) \mathbf{B}_{1} \mathbf{U}_{1}+\left(\mathbf{A}_{2}-\mathbf{I}\right)^{-1}\left(\mathbf{A}_{2}^{M}-\mathbf{I}\right) \mathbf{B}_{2} \mathbf{U}_{2}\right]
$$

The time points of state variables within a switching cycle at steady state can be readily calculated using (9) and (15), and the calculated results will be used for the calculations of the loss in each resistor and the output power:

1) Loss in each resistor:

$$
E_{R}=f_{s} \sum_{n=1}^{N} R_{i} I_{R}^{2}(n) \frac{T}{N}=\frac{1}{N} \sum_{n=1}^{N} R I_{R}^{2}(n)
$$

2) Output power:

$$
E_{o}=f_{s} \sum_{n=1}^{N} V_{10}(n) I_{o} \frac{T}{N}=\frac{1}{N} \sum_{n=1}^{N} I_{o} V_{10}(n) .
$$

The overall efficiency can be calculated as

$$
\eta=\frac{E_{o}}{E_{o}+\sum E_{R}} \times 100 \%,
$$

where $\sum E_{R}$ is the sum of all resistive losses including the losses of $R_{d s \text { on }}$ of the switches.

\section{B. Efficiency estimation of the morphing SC converter with $N$ modules}

For the morphing SC converter with $N$ modules, the first step is to determine the working mode of the converter. According to (18), the efficiency of each working module can be calculated. Therefore, the overall efficiency of the morphing SC converter is

$$
\eta_{\text {all }}=\prod_{i=1}^{k} \eta_{i}
$$

where $k$ is the number of working modules and $\eta_{i}$ is the calculated efficiency of $i$-th module according to (18).

\section{EXPERIMENT RESULTS}

A prototype is built to verify the performance of the proposed morphing SC converter. The components used are shown in Table II. Fig. 11 is the schematic of the control circuit. The control parameters of the two-module morphing SC converter are shown in Table III. A single module of the SC cell is shown in Fig. 12.

TABLE II

COMPONENTS USED IN THE MODULE OF SINGLE SC CELL.

\begin{tabular}{|c|c|}
\hline Component & Part no. \\
\hline$C_{10}$ & $2 \times 47 \mu \mathrm{F}$ (two GEM32ER61C476K paralleled) \\
\hline$C_{11}$ & $2 \times 47 \mu \mathrm{F}$ (two GEM32ER61C476K paralleled) \\
\hline$C_{f 1}$ & $6 \times 47 \mu \mathrm{F}$ (six GEM32ER61C476K paralleled) \\
\hline$S_{0}$ & SIS443DN \\
\hline$S_{1 A}, S_{1 B}$ & SIS443DN \\
\hline$S_{11 u}, S_{11 d}$ & FDMC7660 \\
\hline$S_{10 u}, S_{10 d}$ & FDMC7660 \\
\hline
\end{tabular}




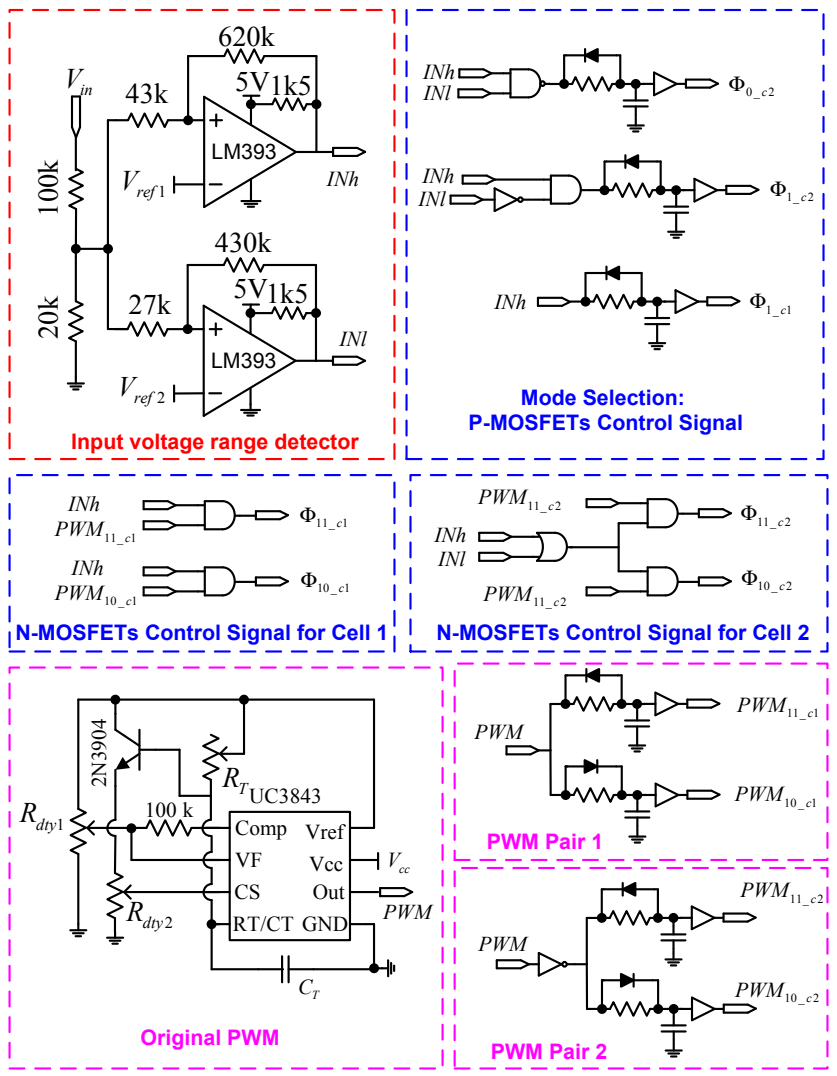

Fig. 11. Control circuit schematic of the two-module morphing SC converter.

TABLE III

CONTROL PARAMETERS OF TWO-MODULE MORPHING SC CONVERTER.

\begin{tabular}{|c|c|}
\hline Component & Part no. \\
\hline$V_{\text {in }}$ & $6 \mathrm{~V}-30 \mathrm{~V}$ \\
\hline$V_{o}$ & $3.5 \mathrm{~V}-8.5 \mathrm{~V}$ \\
\hline$f_{s}$ & $100 \mathrm{kHz}$ \\
\hline$V_{a c t, 12}$ & $8.28 \mathrm{~V}$ \\
\hline$V_{a c t, 23}$ & $17.06 \mathrm{~V}$ \\
\hline$V_{a c t, 32}$ & $15.25 \mathrm{~V}$ \\
\hline$V_{a c t, 21}$ & $5.9 \mathrm{~V}$ \\
\hline
\end{tabular}

\section{A. Size of the Morphing SC Converter}

The power stage of a single module SC cell is shown in Fig. 12. The PCB size is 1.704 inches in length, 1.562 inches in width. The total volume of the power stage is $0.43 \mathrm{in}^{3}$ including the thickness of the PCB, but not including the driver and control circuits in the back side. The PCB used is standard thickness, 0.063 inches, and the maximum component height is determined by the capacitor, which is 0.098 inches. The volumetric breakdown is shown in Fig. 13. The components only take up $4 \%$ of the total power-stage volume, and the PCB takes up 39\%. This indicates that further reduce the volume is possible by reducing the thickness of the PCB. The total volume of the converter including the driver circuits is $0.61 \mathrm{in}^{3}$.

\section{B. Performance of the Two-Module Morphing SC Converter}

(a) Waveforms of two-module morphing SC converter 


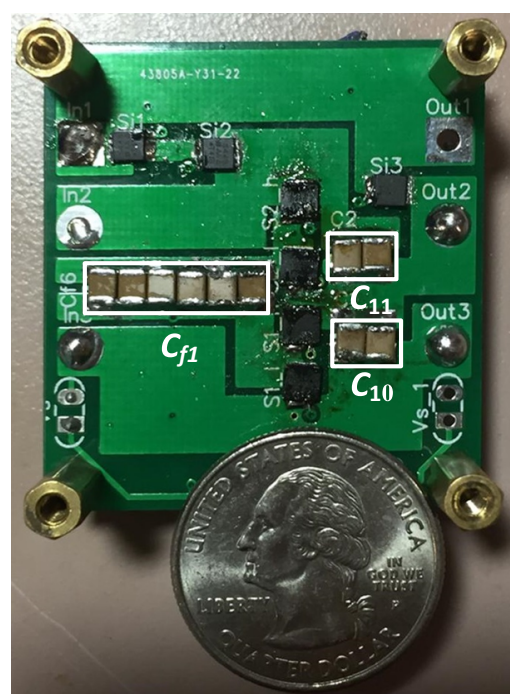

Fig. 12. Power stage of a single module of the SC cell.

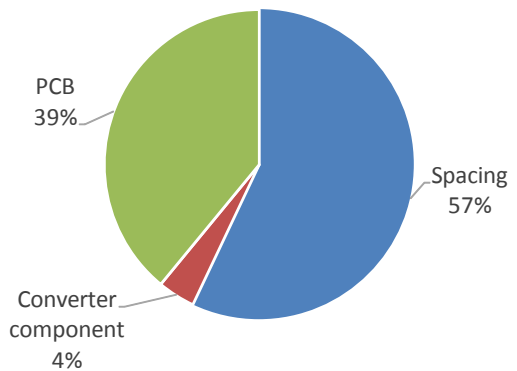

Fig. 13. Converter power stage volume breakdown without considering driver circuit.

The voltage waveforms of the two-module morphing SC converter at $15 \mathrm{~W}$ output is shown in Fig. 14. The morphing waveforms of Mode 1 to Mode 2 and Mode 2 to Mode 3 at $15 \mathrm{~W}$ constant output power are shown in Figs. 15(a) and 15(b), respectively. The waveforms show that the mode morphing is smooth and the dynamic response is fast at around $4 \mathrm{~ms}$. Fig. 16 shows the plot of output voltage of the two-module morphing SC converter with an input voltage of $6 \mathrm{~V}-30 \mathrm{~V}$ at $25 \mathrm{~W}$ load. The output voltage is converted to a relatively smaller voltage range of $3.5 \mathrm{~V}-8.5 \mathrm{~V}$.

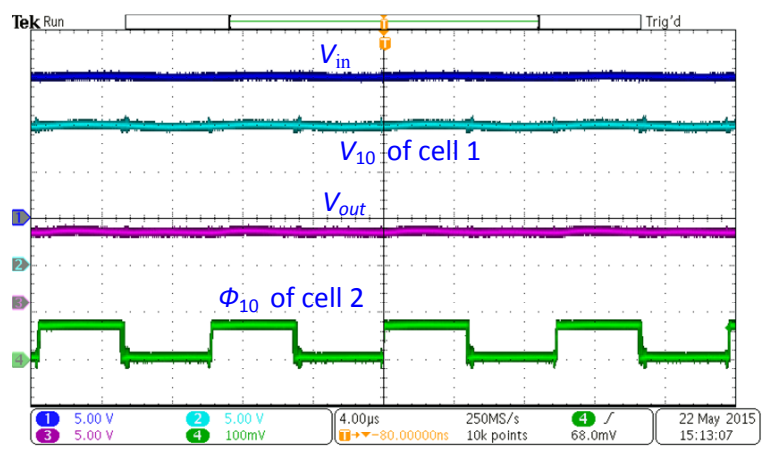

(a)

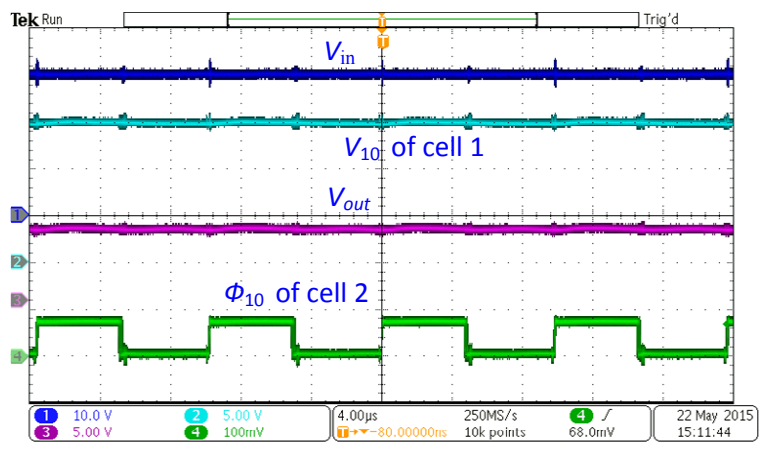

(b)

Fig. 14. Input and output voltage waveforms of the two-module morphing SC converter in (a) Mode 2 and (b) Mode 3 at $15 \mathrm{~W}$ output $100 \mathrm{kHz}$ switching frequency.

(b) Efficiency of two-module morphing SC converter 


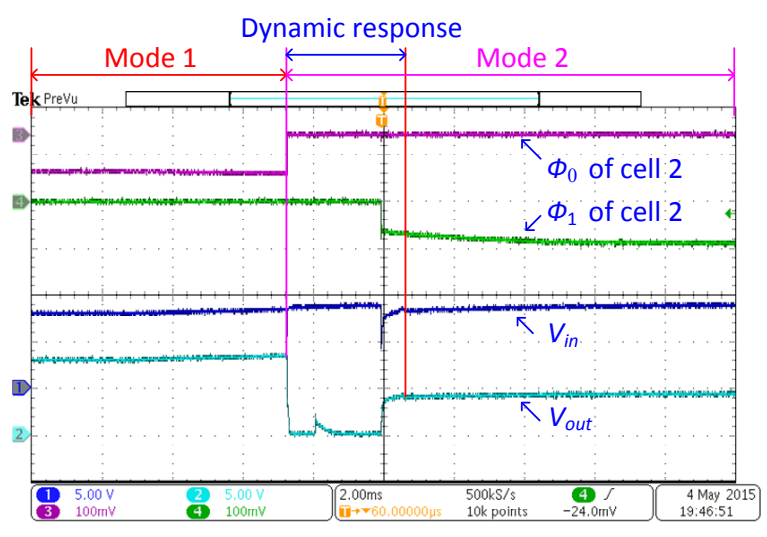

(a)

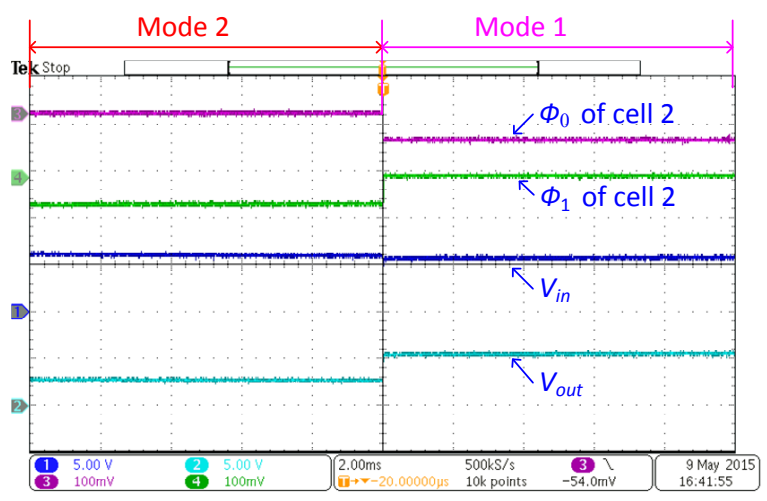

(c)

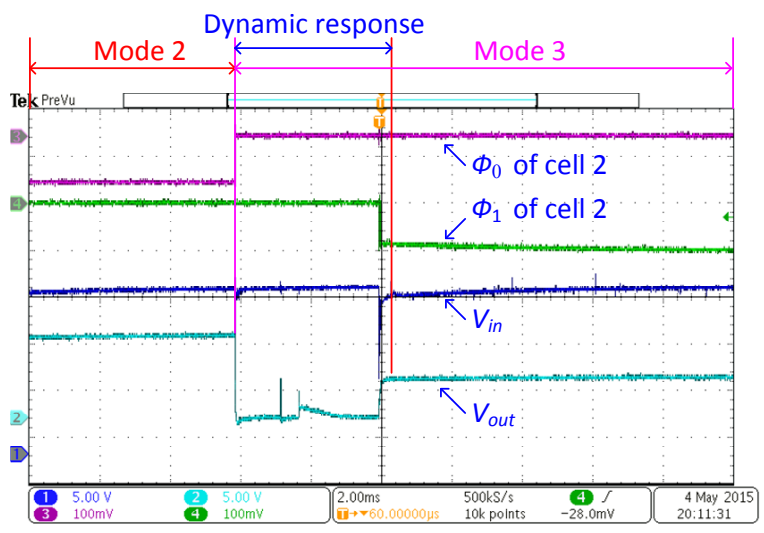

(b)

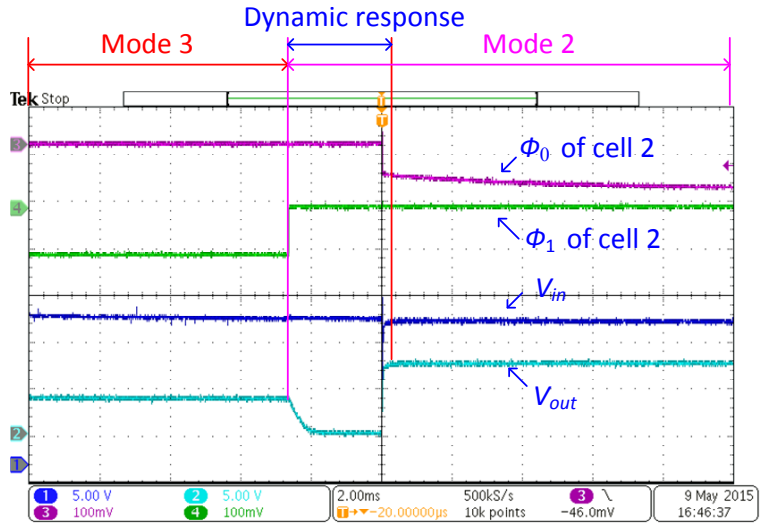

(d)

Fig. 15. Input and output voltage waveforms of morphing from (a) Mode 1 to Mode 2, (b) Mode 2 to Mode 3, (c) Mode 2 to Mode 1, and (d) Mode 3 to Mode 2 of the two-module morphing SC converter at $15 \mathrm{~W}$ output $100 \mathrm{kHz}$ switching frequency.

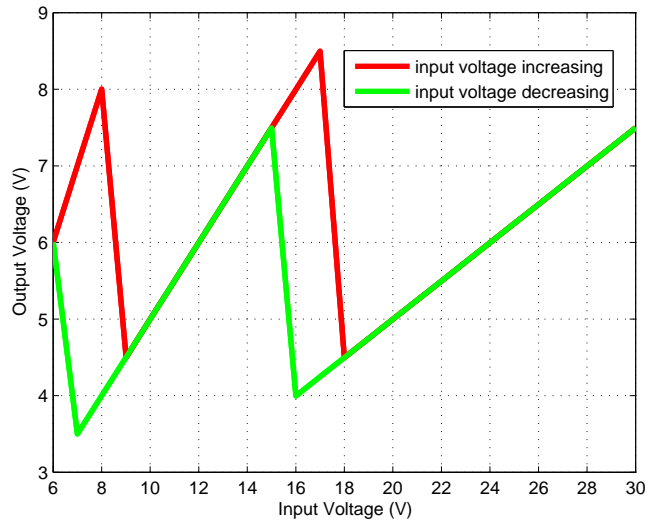

Fig. 16. The output voltage of the two-module morphing SC converter at $25 \mathrm{~W}$ load and $100 \mathrm{kHz}$ switching frequency. 
The efficiency of two-module morphing SC converter in three modes is shown in Figs. 17-19. The measurement is based on a constant output power of $25 \mathrm{~W}$, and the input voltage is varying. Fig. 17 show the efficiency curve of Mode 1 for different input voltage. The efficiency is higher than $99 \%$ when the input voltage is higher than $8 \mathrm{~V}$. The efficiency drops when the input voltage is lower than $8 \mathrm{~V}$. This is because the driver voltage of the P-MOSFET of $S_{0}$ of cell 2 is decreasing with the reduction of the input voltage. This leads to a higher $R_{d s o n}$ of $S_{0}$ of cell 2. Simultaneously, to keep the constant output power, the output current is also increased when the input voltage is decreased. This current also passes through the MOSFET $S_{0}$. Therefore, the loss on MOSFET $S_{0}$ increases, which leads to the drop in efficiency. Fig. 18 is the efficiency curve of the converter in Mode 2 for different input voltage and switching frequency. The results show that the SC converter working at $150 \mathrm{kHz}$ switching frequency has the highest efficiency when the input voltage is lower than $18 \mathrm{~V}$. When the input voltage is higher than $18 \mathrm{~V}$, a lower switching frequency leads to a higher efficiency. Fig. 19 is the efficiency curve of the SC converter in Mode 3 for different input voltage. The results shows that the SC converter working at $150 \mathrm{kHz}$ switching frequency has a highest efficiency when the input voltage is lower than $20 \mathrm{~V}$, and for an input voltage higher than $20 \mathrm{~V}$, the highest efficiency is at $100 \mathrm{kHz}$ switching frequency. Figs. 17-19 also verify the accuracy of the calculation results.

Fig. 20 shows the efficiency curve of the two-module morphing SC converter with a $30 \mathrm{~V}$ input voltage, $100 \mathrm{kHz}$ switching frequency and varying output power. The results show that the maximum efficiency is high and closed to $98 \%$ over the entire load range, which is between $20 \mathrm{~W}$ to $80 \mathrm{~W}$ for Mode 2. The peak efficiency in Mode 3 is as high as $95.9 \%$.

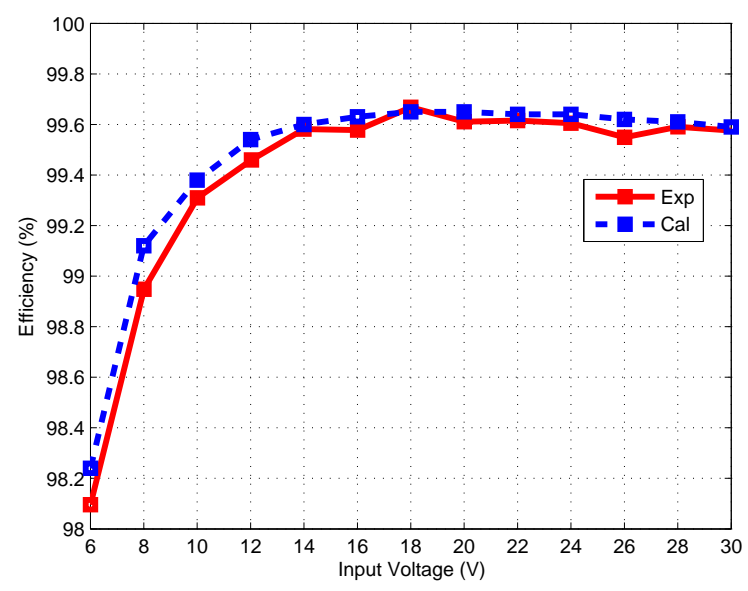

Fig. 17. The experiment and calculation efficiency curves of two-stage morphing SC converter at Mode 1 with $25 \mathrm{~W}$ constant power output (Exp: experiment result, Cal: calculation result).

\section{Two-Module Morphing SC Converter Applied in Two-Stage Converter}

One application example of the two-module SC morphing converter is the two-stage converter shown in Fig. 21(a). The first-stage converter is the morphing SC converter as shown in Fig. 6, and the second-stage is a buck converter, which is shown in Fig. 21(b). The main parameters are shown in Table IV.

The efficiency of two-stage converter, which comprises the two-module morphing SC converter prototype as the first-stage converter and commercial IC IR3820 as the second-stage buck converter is shown in Fig. 22. The two-stage converter has a high efficiency over the entire range of the input voltage between $6 \mathrm{~V}$ and $30 \mathrm{~V}$. The efficiency is higher than $80 \%$ over the entire range, which is higher than the buck converter itself. Moreover, the applicable input voltage range is also extended with the incorporation of the SC converter. 


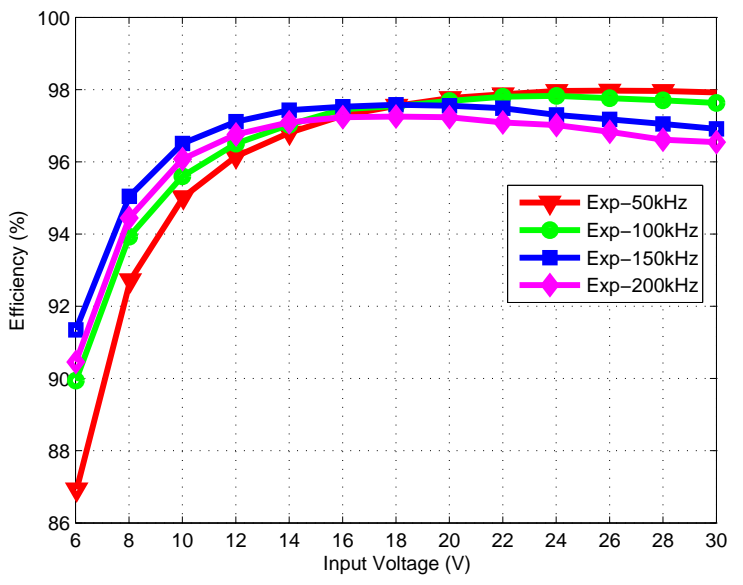

(a)

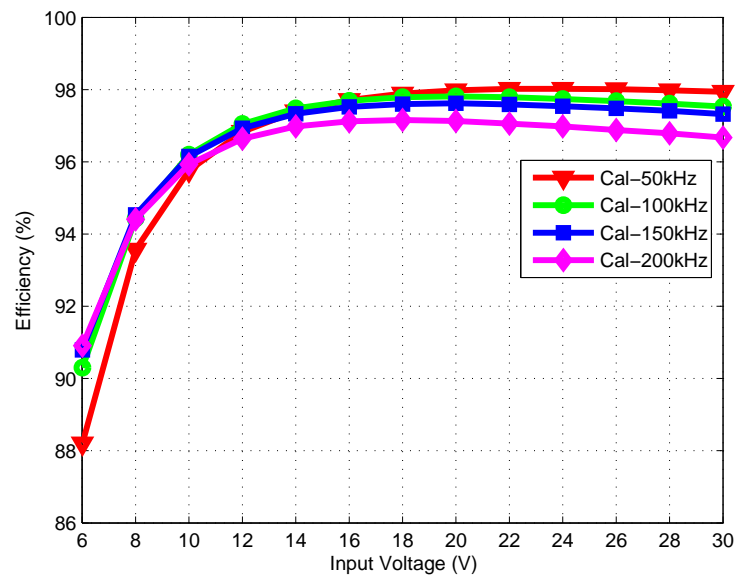

(b)

Fig. 18. The (a) experiment and (b) calculation efficiency curves of two-stage morphing SC converter at Mode 2 with $25 \mathrm{~W}$ constant power output.

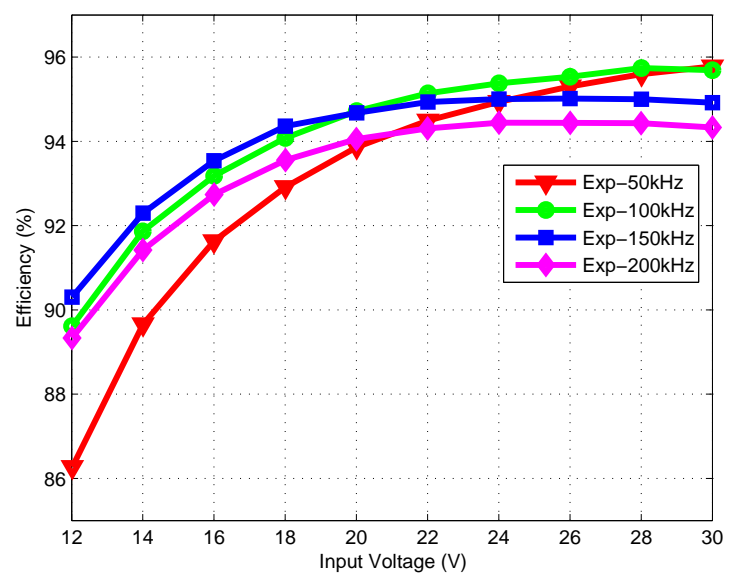

(a)

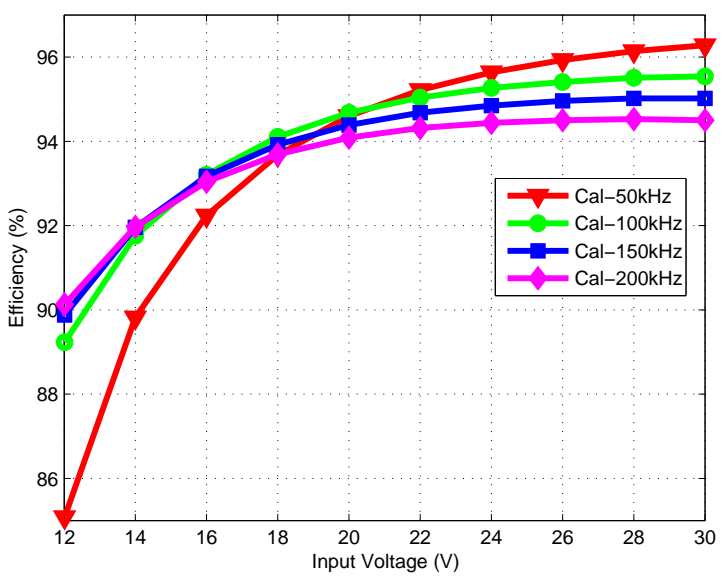

(b)

Fig. 19. The (a) experiment and (b) calculation efficiency curves of two-stage morphing SC converter at Mode 2 with $25 \mathrm{~W}$ constant power output.

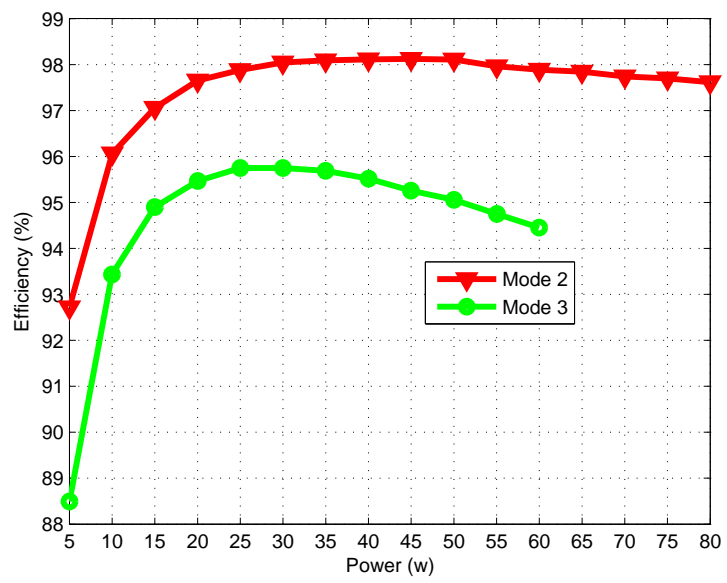

Fig. 20. Efficiency curves of mode 2 and 3 of two-module SC converter at $30 \mathrm{~V}$ input $100 \mathrm{kHz}$ switching frequency. 


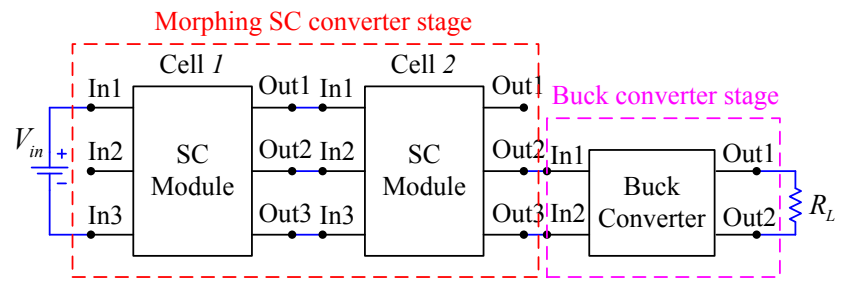

(a)

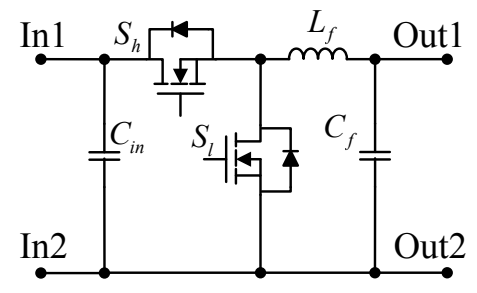

(b)

Fig. 21. (a) The block diagram of the morphing SC-buck converter and (b) the circuit diagram of the buck converter.

TABLE IV

MAIN PARAMETERS OF THE BUCK CONVERTER.

\begin{tabular}{|c|c|}
\hline IC type & IR3820 \\
\hline Input voltage & $2.5-21 \mathrm{~V}$ \\
\hline Output voltage & $1.8 \mathrm{~V}$ \\
\hline Switching frequency & $300 \mathrm{kHz}$ \\
\hline Filter inductor & $1.7 \mu \mathrm{H}$ \\
\hline Output capacitor & $2 \times 47 \mu \mathrm{F}$ \\
\hline
\end{tabular}

\section{CONCLUSiOnS}

A morphing SC converter, which is high-voltage-gain and suitable for wide-input-range application, is proposed. This morphing SC converter is adaptive to the magnitude of the input voltage as the converter's conversion ratio is variable through the morphing of the structure of the converter. The morphing SC converter is easily extendable through the cascade of extra SC cell. It is experimentally demonstrated that a high efficiency, small volume, and light weight morphing SC converter is achievable. When the morphing SC converter is applied as the front-end converter in a two-stage converter, the overall efficiency of the two-stage converter is improved as compared with that of a single buck converter. Moreover, the morphing SC converter can also extend the input voltage range of the buck converter. Therefore, the morphing SC converter is a good option for the high-voltage-gain and wide-input-range application.

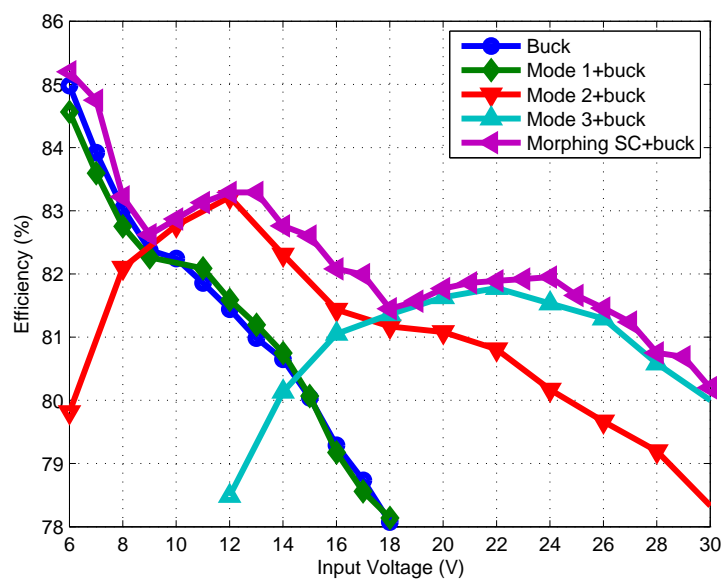

Fig. 22. The efficiency curve of the morphing SC-buck converter at $15 \mathrm{~W}$ output power in different modes. 


\section{REFERENCES}

[1] K. K. Leong, G. Deboy, K. Krischan, and A. Muetze, "A single stage $54 \mathrm{~V}$ to $1.8 \mathrm{~V}$ multi-phase cascade buck voltage regulator module," in IEEE Appl. Power Electron. Conf. and Exposit. (APEC), pp. 1966-1973, Mar. 2015.

[2] S. G. Luo and I. Batarseh, "A review of distributed power systems part I: DC distributed power system," IEEE Magaz. of Aerosp. and Electron. Syst., vol. 20, no. 8, pp. 5-16, Aug. 2005.

[3] C. Schaef and J. T. Stauth, "A multilevel VR implementation and MIMO control scheme for vertically stacked microprocessor cores," in IEEE Appl. Power Electron. Conf. and Exposit. (APEC), pp. 2090-2096, Mar. 2015.

[4] Application Note, "Choosing the right DC-DC converter for automotive applications," http://www.maximintegrated.com/cn/app-notes/index.mvp/id/1845.

[5] R. Guo, Z. G. Liang, and A. Q. Huang, "A family of multimodes charge pump based DC-DC converter with high efficiency over wide input and output range," IEEE Trans. on Power Electron., vol. 27, no. 11, pp. 4788-4798, Nov. 2012.

[6] L. Q. Chen, H. F. Wu, P. Xu, H. B. Hu, and C. G. Wan "A high step-down non-isolated bus converter with partial power conversion based on synchronous LLC resonant converter," in IEEE Appl. Power Electron. Conf. and Exposit. (APEC), pp. 1950-1955, Mar. 2015.

[7] J. Sun, M. Xu, Y. Ying, and F. C. Lee, "High power density high efficiency system two-stage power architecture for laptop computers," in IEEE Power Electron. Spec. Conf. Rec. (PESC), pp. 4008-4015, Jun. 2006.

[8] M. Xu, J. Sun, and F. C. Lee, "Voltage divider and its application in the two-stage power architecture," in IEEE Appl. Power Electron. Conf. and Exposit. (APEC), vol. 2, pp. 499-505, Mar. 2006.

[9] Datasheet of IR3820, http://www.irf.com/product-info/datasheets/data/ir3820am.pdf

[10] X. B. Ruan, W. Chen, L. L. Cheng, C. K. Tse, H. Yan, and T. Zhang, "Control strategy for input-series-ouput-parallel converters," IEEE Trans. on Industr. Electron., vol. 56, no. 4, pp. 1174-1185, Apr. 2009.

[11] W. H. Li, S. Zong, F. R. Liu, H. Yang, X. N. He, and B. Wu, "Secondary-side phase-shift-controlled ZVS DC/DC converter with wide voltage gain for high input voltage applications," IEEE Trans. on Power Electron., vol. 28, no. 11, pp. 5128-5139, Nov. 2013.

[12] H. F. Wu, C. G. Wan, K. Sun, and Y. Xing, "A high step-down multiple output converter with wide input voltage range based on quasi two-stage architecture and dual-output LLC resonant converter," IEEE trans. on Power Electron., vol. 30, no. 4, pp. 1793-1796, Apr. 2015.

[13] E. S. Kim, J. H. Park, J. S. Joo, S. M. Lee, K. Kim, and Y. S. Kong, "Bidirectional DC-DC converter using secondary LLC resonant tank," in IEEE Appl. Power Electron. Conf. and Exposit. (APEC), pp. 2104-2108, Mar. 2015.

[14] D. Patil, A. K. Rathore, and D. Srinivasan, "A non-isolated bidirectional soft switching current fed LCL resonant DC-DC converter to interface energy storage in DC microgrid," in IEEE Appl. Power Electron. Conf. and Exposit. (APEC), pp. 709-716, Mar. 2015.

[15] D. Doncker, D. M. Divan, and M. H. Kheraluwala, "A three-phase soft-switched high-power-density DC/DC converter for high-power applications," IEEE Trans. on Indust. Applic., vol. 27, no. 1, pp. 63-73, Jan./Feb. 1991.

[16] L. Zhu, "A novel soft-commutating isolated boost full-bridge ZVS-PWM DC-DC converter for bidirectional high power applications," IEEE Tran. on Power Electron., vol. 21, no. 2, pp. 422-429, Mar. 2006.

[17] W. H. Li and X. N. He, "Review of non-isolated high-step-up DC/DC converters in photovoltaic grid-connected applications," IEEE Tran. on Ind. Electron., vol. 58, no. 4, pp. 1239-1250, Apr. 2011.

[18] J. M. Kwon and B. H. Kwon, "High step-up active-clamp converter with input-current doubler and output-voltage doubler for fuel cell power systems," IEEE Tran. on Power Electron., vol. 24, no. 1, pp. 108-115, Jan. 2009.

[19] R. D. Middlebrook, "Transformerless DC-to-DC converters with large conversion ratios," IEEE Trans. on Power Electron., vol. 3 no. 4, pp. 484-488, Oct. 1988.

[20] J. Wei, P. Xu, H. P. Wu, F. C. Lee, K. Yao, and M. Ye, "Comparison of three topology candidates for 12 V VRM," in IEEE Appl. Power Electron. Conf. and Exposit.(APEC), pp. 245-251, Mar. 2001.

[21] B. Axelrod, Y. Berkovich, and A. Ioinovici, "Switched-capacitor/switched-inductor structures for getting transformerless hybrid DC-DC PWM converters," IEEE Tran. on Cir. and Sys., vol. 55 no. 2, pp. 687-696, Mar. 2008.

[22] Y. H. Chang, "Variable-conversion-ratio switched-capacitor-voltage-multiplier/divider DC-DC converter," IEEE Trans. on Cir. and Sys.-I: Regular Papers, vol. 58, pp. 1944-1957, Aug. 2011.

[23] S. Xiong, S. C. Tan, and S. C. Wong, "Analysis and design of a high-voltage-gain hybrid switched-capacitor buck converter" IEEE Trans. on Cir. Sys. I, Regul. Pap., vol. 59, no. 5, pp. 1132-1141, May. 2012.

[24] R. C. N. Pilawa-Podgurski, D. M. Giuliano, and D. J. Perreault, "Merged two-stage power converter with soft charging switched-capacitor stage in 180 nm CMOS," IEEE Jour. of Solid-state. Cir., vol. 47, no. 7, pp. 1557-1567, July 2012.

[25] S. Xiong, S. C. Wong, S. C. Tan, and C.K. Tse, "A family of exponential step-down switched-capacitor converters and their applications in two-stage converters," IEEE Trans. on Power Electron., vol. 29, no. 4, pp. 1870-1880, Apr. 2014.

[26] S. V. Cheong, H. Chung, and A. Ioinovici, "Inductorless DC-DC converter with high power density," IEEE Trans. on Ind. Electron., vol. 41, no. 2, pp. 208-215, Apr. 1994. 
[27] H. S. H. Chung and W. C. Chow, "Development of switched-capacitor-based DC-DC converter with bi-directional power flow," in IEEE Int. Symp. Circu. Syst. (ISCAS), vol. 5, pp. 202-205, May 1999.

[28] M. S. Makowski and D. Maksimovic, "Performance limits of switched-capacitor DC-DC converters," in IEEE Power Electron. Special. Conf. (PESC), vol. 2, pp. 1215-1221, Jun. 1995.

[29] D. Maksimovic and S. Dhar, "Switched-capacitor DC-DC converters for low-power on-chip applications," in IEEE Power Electron. Special. Conf. (PESC), vol. 1, pp. 54-59, Aug. 1999.

[30] H. S. H. Chung, S. Y. R. Hui, S. C. Tang, and A. Wu, "On the use of current control scheme for switched-capacitor DC/DC converters," IEEE Trans. on Ind. Electron., vol. 47, no. 2, pp. 238-244, Apr. 2000.

[31] A. Ioinovici, "Switched-capacitor power electronics circuits," IEEE Circuits Syst. Mag., vol. 41, no. 2, pp. 37-42, Sept. 2001.

[32] J. W. Kimball and P. T. Krein, "Analysis and design of switched capacitor converters," in IEEE Appl. Power Electron. Conf. and Exposit. (APEC), vol. 3, pp. 1473-1477, Mar. 2005.

[33] M. S. Makowski, "On performance limits of switched-capacitor multi-phase charge pump circuits. remarks on papers of starzyk et al." in Int. Conf. on Sign. and Electron. Syst. (ICSES), pp. 309-312, Sept. 2008.

[34] F. Zhang, L. Du, F. Z. Peng, and Z. ming Qian, "A new design method for high-power high-efficiency switched-capacitor DC-DC converters," IEEE Trans. on Power Electron., vol. 23, no. 2, pp. 832-840, Mar. 2008.

[35] V. W. Ng, M. D. Seeman, and S. R. Sanders, "High-efficiency, 12V-TO-1.5V DC-DC converter realized with switched-capacitor architecture," in Symp. on VLSI Circ., pp. 168-169, Jun. 2009.

[36] S. C. Tan, S. Kiratipongvoot, S. Bronstein, A. Ioinovici, Y. M. Lai, and C. K. Tse, "Interleaved switched-capacitor converters with adaptive control," in IEEE Energy Convers. Congr. Exposit. (ECCE), pp. 2725-2732, Sep. 2010.

[37] V. W. Ng, M. D. Seeman, and S. R. Sanders, "Minimum pcb footprint point-of-load DC-DC converter realized with switched-capacitor architecture," in IEEE Energ. Convers. Congr. and Exposit.(ECCE), pp. 1575-1581, Sept. 2009.

[38] D. Cao, X. H. Yu, X. Lu, W. Qian, and F. Z. Peng, "A double-wing multilevel modular capacitor-clamped DC-DC converter with reduced capacitor voltage stress," in IEEE Energ. Convers. Congr. and Exposit. (ECCE), pp. 545-552, Sept. 2011.

[39] J. M. Henry and J. W. Kimball, "Practical performance analysis of complex switched-capacitor converters," IEEE Trans. on Power Electron., vol. 26, no. 1, pp. 127-136, Jan. 2011.

[40] W. Qian, D. Cao, J. G. Cintron-Rivera, M. Gebben, D. Wey, and F. Z. Peng, "A switched-capacitor DC-DC converter with high voltage gain and reduced component rating and count," IEEE Trans. on Ind. Electron., vol. 48, no. 4, pp. 1397-1406, July-Aug. 2012.

[41] K. Zou, M. J. Scott, and J. Wang, "A switched-capacitor voltage tripler with automatic interleaving capability," IEEE Trans. on Power Electron., vol. 27, no. 6, pp. 2857-2868, Jun. 2012.

[42] S. Ben-Yaakov and M. Evzelman, "Generic average modeling and simulation of the static and dynamic behavior of switched capacitor converters," in IEEE Appl. Power Electron. Conf. and Exposit. (APEC), pp. 2568-2575, Feb. 2012.

[43] M. Evzelman and S. Ben-Yaakov, “Average-current-based conduction losses model of switched capacitor converters," IEEE Trans. on Power Electron., vol. 28, no. 7, pp. 3341-3352, Jul. 2013.

[44] D. Cao, S. Jiang, and F. Z. Peng, "Optimal design of a multilevel modular capacitor-clamped DC-DC converter," IEEE Trans. on Power Electron., vol. 28, no. 8, pp. 3816-3826, Aug. 2013.

[45] M. Evzelman S. Ben-Yaakov, "Simulation of hybrid converters by average models," IEEE Trans. on Ind. Applic. vol. 50, no. 2, pp. 1106-1113, Mar.-Apr. 2014.

[46] B. Wu, S. Li, K. Smedley, and S. Singer, "A family of two-switch boosting switched-capacitor converters," IEEE Trans. on Power Electron., early access paper.

[47] T. Santa, M. Auer, C. Sandner, and C. Lindholm, "Switched capacitor DC-DC converter in 65nm CMOS technology with a peak efficiency of 97\%," in IEEE Inter. Symp. on Cir. and Sys. (ISCAS), pp. 1351-1354, May 2011.

[48] T. M. Andersen, F. Krismer, J. W. Kolar, T. Toifl, C. Menolfi, L. Kull, T. Morf, M. Kossel, M. Brandli, P. Buchmann, and P. A. Francese, “A 4.6W/mm² power density $86 \%$ efficiency on-chip switched capacitor DC-DC converter in $32 \mathrm{~nm}$ SOI CMOS," in IEEE Appl. Power Electron. Conf. and Exposit. (APEC), pp. 692-699, Mar. 2013.

[49] T. M. Andersen, F. Krismer, J. W. Kolar, T. Toifl, C. Menolfi, L. Kull, T. Morf, M. Kossel, M. Brandli, P. Buchmann, and P. A. Francese, "A deep trench capacitor based 2:1 and 3:2 reconfigurable on-chip switched capacitor DC-DC converter in $32 \mathrm{~nm}$ SOI CMOS," in IEEE Appl. Power Electron. Conf. and Exposit. (APEC), pp. 1448-1455, Mar. 2014. 